\title{
PENGARUH VARIASI VOLUME PENGGUNAAN REAGENSIA TERHADAP KADAR GLUKOSA DARAH METODE GOD-PAP (GLUKOSA OXIDASE PEROKXIDASE AMINOANTIPYRINE PHENOL)
}

\author{
Muhammad Nasir ${ }^{1}$, A. Rasdiana ${ }^{2}$ \\ 1,2Jurusan Analis Kesehatan Poltekkes Kemenkes Makassar
}

Koresponden : nasir@ poltekkes-mks.ac.id

\begin{abstract}
ABSTRAK
Penelitian ini berlatarbelakang pada metode pemeriksaan yang tidak sesuai dengan prosedur pemeriksaan yang ada, salah satunya adalah pemeriksaan glukosa darah.Tujuan dari penelitian ini adalah untuk melihat pengaruh Variasi Volume penggunaan Reagensia pada pemeriksaan glukosa darah metode GOD-PAP (Glukosa Oxidase Peroksidase Aminoantypyrine Phenol). Penelitian ini bersifat ekperimen semu dengan menggunakan teknik pengambilan sampel yaitu Accidental sampling dengan besar sampel 9 sampel. Data disajikan dengan uji Anova. Hasil analisa data dengan menggunakan uji Anova diperoleh Fhitung (6,74 ) > Ftabel $(3,40)$,sehinggah dapat disimpulkan bahwa terdapat pengaruh Variasi penggunaan reagensia pada pemeriksaan glukosa darah metode GOD-PAP. Untuk melakukan pemeriksaan glukosa darah variasi volume reagen warna harus tepat,tidak boleh ada pengurangan volume reagen
\end{abstract}

Kata Kunci : Variasi Volume, Reagensia, Glukosa Darah

\section{PENDAHULUAN}

Pada umunya diagnosis penyakit dibuat berdasarkan gejala penyakit (keluhan dan tanda dan gejala ini mengarahkan dokter pada kemungkinan penyebab penyakit. Dengan adanya pemeriksaan laboratorium ini sangatlah membantu dokter untuk menetapkan penyakit apa yang dialami oleh seorang pasien

Fungsi utama karbohidrat dari makanan yang di komsumsi adalah sebagai sumber energi.Tubuh menggunakan glukosa sebagai sumber utama energy bagi sel-sel jaringan sekitar setengah energy yang digunakan oleh otot dan jaringan lain berasal dari glukosa dan glikogen, tetapi yang di komsumsi adalah sumbernya, yaitu glukosa berasal dari pati sedangkan glikogen dari pangan hewani.

Para ahli gizi dan kesehatan merekomendasikan kansumsi karbohidrat sebanyak 45-60\% dari jumlah kalori yang dikomsumsi per hari.Sebagian besar karbohidrat tersebut harus berasal dari bahan pangan bukan berasal dari gula, karena makanan yang berasal dari gula tidak menyehatkan. (Muchtaday D, 2011)

Menurut paradigma sehat, diharapkan orang tetap sehat dan lebih sehat sedang yang berpenyakit lekas dapat disembuhkan agar sehat. Untuk segera disembuhkan, perlu ditentukan penyakitnya dan pengobatan yang tepat, serta prognosis atau ramalan penyakitnya 
yaitu ringan, berat atau lafal. (Hardjono, 2007)

Dalam menentukan penyakit atau diagnosis, maka dilakukan tes laboratorium salah satunya adalah pemeriksaan kadar glukosa darah metode Glukosa oksidase Peroksidasi Aminoantypyine Phenol (GODPAP).Suatu enzim bakteri yang merangsang oksidase glukosa dengan menghasilkan $\mathrm{H}_{2} \mathrm{O}_{2}$ dengan adanya METODE

Jenis penelitian ini adalah eksperimen semu terhadap pengaruh variasi penggunaan reagensia pada pemeriksaan glukosa darah metode Glukosa Oxidase Peroxidase Aminoantipyrine Phenol (GOD-PAP) penelitian dilaksanakan di laboratorium Kimia Klinik Jurusan Analis Kesehatan Poltekkes Kemenkes Makassar pada tanggal bulan Juni 2015

Sampel pada penelitian ini adalah darah EDTA sebanyak 9 sampel dengan teknik pengambilan sampel dalam penelitian ini adalah Accidental sampling.

Instrrumen yang digunakan dalam penelitian ini adalah Humalyzer 2000,tabung reaksi, mikropipet $10 \mu \mathrm{l}, 850 \mu \mathrm{l}, 1000 \mu \mathrm{l}, 1200 \mu \mathrm{l}$, rak tabung. Bahan penelitian yang digunakan dalam penelitian ini adalah serum dan reagen pemeriksaan glukosa darah metode GOD-PAP Prosedur Kerja

Prosedur kerja pemeriksaan glukosa darah metode GOD-PAP dengan variasi penggunaan reagen.

Sampel A dibagi menjadi 3 bagian, diberi label a1, a2, a3, masing-masing dipipet sebanyak 10 enzim peroksidase oksigen dari peroksida ini di alihkan ke acceptor tertentu menghasilkan suatu ikatan berwarna.

Berdasarkan latar belakang di atas maka peneliti telah melakukan penelitian tentang pengaruh variasi volume reagensia terhadap kadar glukosa darah metode GOD-PAP

$\mu$ l. Sampel a1 ditambahkan $850 \mu 1$ reagen, a2 ditambahkan $1000 \mu \mathrm{l}$ reagen, dan sampel a3 ditambahkan $1200 \mu \mathrm{l}$ reagen. Dilakukan perlakuan yang sama dengan sampel B dan seterusnya. Untuk standar dipipet 10 $\mu \mathrm{l}$ dan ditambah $1000 \mu \mathrm{l}$ reagen, standar digunakan untuk semua sampel. Untuk blanko dipipet reagen $1000 \mu \mathrm{l}$. Dihomogenkan dan diinkubasi selama 5 menit pada suhu $37^{\circ} \mathrm{C}$. Membaca absorban dan standar terhadap blanko reagen sebelum 60 menit.

Analisa data

Data yang terkumpul ditabulasi kemudian diuji secara statistic dengan uji ANOVA

\section{HASIL}

Berdasarkan penelitian yang telah dilakukan terhadapPengaruh Variasi Volume Penggunaan Reagensia Terhadap Kadar Glukosa Darah metode GOD-PAP diLaboratorium Kimia Klinik Poltekkes Makassar pada tanggal 11 Juni 2015 sebanyak 9 sampel diperoleh hasil seperti yang tercantum pada tabel 
Tabel 1. Hasil pemeriksaan kadar glukosa darah dengan variasi volume penggunaan reagensia

\begin{tabular}{|c|c|c|c|c|}
\hline \multirow[t]{2}{*}{ No } & \multirow[t]{2}{*}{$\begin{array}{c}\text { Kode } \\
\text { Sampel }\end{array}$} & \multicolumn{3}{|c|}{$\begin{array}{l}\text { Kadar Glukosa darah } \\
\text { Dengan Variasi Volume } \\
\text { Reagensia (mg/dl) }\end{array}$} \\
\hline & & $850 \mu l$ & $1000 \mu \mathrm{l}$ & $1200 \mu \mathrm{l}$ \\
\hline 1 & A & 102 & 83 & 62 \\
\hline 2 & B & 120 & 98 & 72 \\
\hline 3 & $\mathrm{C}$ & 128 & 104 & 86 \\
\hline 4 & D & 184 & 150 & 127 \\
\hline 5 & $\mathrm{E}$ & 105 & 84 & 70 \\
\hline 6 & $\mathrm{~F}$ & 130 & 110 & 92 \\
\hline 7 & G & 90 & 72 & 59 \\
\hline 8 & $\mathrm{H}$ & 116 & 95 & 76 \\
\hline 9 & I & 126 & 108 & 92 \\
\hline & Total & 1101 & 904 & 736 \\
\hline & ata-ata & 123 & 100,4 & 81,7 \\
\hline & $\begin{array}{l}\text { umlah } \\
\text { gamatan } \\
\text { (n) }\end{array}$ & 9 & 9 & 9 \\
\hline
\end{tabular}

\section{Sumber : Data Primer 2015}

Berdasarkan pada tabel hasil pemeriksaan menunjukkan apabila reagen dikurangi maka hasil pemeriksaan glukosa akan meningkat dan apabila reagen ditambah maka hasil akan menjadi lebih rendah dari yang sebenarnya.

Pada tabel menunjukkan hasil pemeriksaan glukosa darah metode GOD-PAP yang menggunakan variasi voleme reagensia 850 $\mu 1,1000 \mu \mathrm{I}$,dan $1200 \mu 1$ menunjukkan hasil yang berbeda.

Pada volume reagensia $850 \mu 1$ nilai terendah untuk hasil pemeriksaan glukosa darah adalah 90 $\mathrm{mg} / \mathrm{dl}$, nilai tertinggi adalah 184 $\mathrm{mg} / \mathrm{dl}$ dan rata-ratanya adalah 123 $\mathrm{mg} / \mathrm{dl}$.Pada volume reagensia $1000 \mu \mathrm{l}$ nilai terendah untuk hasil pemeriksaan gluksa darah adalah 72 $\mathrm{mg} / \mathrm{dl}$,nilai tertinggi adalah $150 \mathrm{mg} / \mathrm{dl}$ dan rata-ratanya adalah 100,4 $\mathrm{mg} / \mathrm{dl}$.Pada volume reagensia $1200 \mu \mathrm{l}$ nilai terendah untuk hasil pemeriksaan glukosa darah adalah 59 $\mathrm{mg} / \mathrm{dl}$, nilai tertinggi adalah 127 $\mathrm{mg} / \mathrm{dl}$ dan nilai rata-ratanya adalah $81,7 \mathrm{mg} / \mathrm{dl}$

Perbedaan hasil glukosa darah pada volume $850 \mu \mathrm{l}$ dengan $1000 \mu \mathrm{l}$ ,sedangkan perbedaan hasil glukosa darah pada volume $1000 \mu \mathrm{l}$ dengan $1200 \mu 1$

Berdasarkan data diatas, dilakukan uji Anova untuk mengetahui ada pengaruh variasi volume penggunaan reagensia pada pemeriksaan glukosa darah metode GOD-PAP.Hasil uji Anova pengaruh variasi volume penggunaan reagensia pada pemeriksaan glukosa darah metode GOD-PAP sebagai berikut : 
Tabel 2 Hasil Uji Anova terhadap pemeriksaan kadar glukosa darah dengan variasi volume penggunaan reagensia.

\begin{tabular}{cccccc}
\hline $\begin{array}{c}\text { Sumber } \\
\text { variasi }\end{array}$ & Db & JK & KT & Fhit & Ftabel \\
\hline Perlakuan & 2 & 7416,963 & 3708,4815 & 6,74 & 3,40 \\
Sisa & 24 & 13197,778 & 549,907417 & & \\
Total & 26 & 20614,741 & & & \\
\hline
\end{tabular}

Berdasarkan tabel diatas maka hasil menunjukkan bahwa $\mathrm{F}$ hit $>$ dari $\mathrm{F}$ tabel $(6,74>3,40)$ maka $\mathrm{Ha}$ diterima Ho ditolak. Artinya terdapat pengaruh Variasi Volime Reagensia Terhadap hasil Pemeriksaan Glukosa.

\section{PEMBAHASAN}

Penelitian ini bersifat eksperimen semu yang bertujuan untuk mengetahui pengaruh variasi volume penggunaan reagensia pada pemeriksaan glukosa darah metode GOD-PAP.

Pemeriksaan kimia darah, khususnya pemeriksaan kadar glukosa merupakan salah satu parameter penting dalam mendiagnosa suatu penyakit serta mengevaluasi tindakan medic atau memantau perkembangan suatu penyakit termasuk diabetes mellitus (DM).Salah satu metode yang sering digunakan adalah metode GOD-PAP. Idealnya tes laboratorium harus tepat (presisi) dan teliti (akurasi).Presisi berarti kemampuan untuk mendapatkan nilai yang hampir sama dengan pada tes berulang-ulang dengan metode yang sama.sedangkan akurasi berarti kemampuan untuk mendapatkan nilai benar yang diinginkan. (Hardjono, 2007)

Berdasarkan data yang diperoleh dari hasil penelitian kemudian dilakukan uji Anova yang menunjukkan bahwa nilai Fhitung $(6,74)>$ Ftabel (3,40 ) maka Ha diterima sedangkan Ho ditolak artinya terdapat pengaruh variasi volume penggunaan reagensia pada pemeriksaan glukosa darah metode GOD-PAP.

Dari hasil penelitian tersebut setelah dilakukan analisa statistik terlihat memberikan pengaruh signifikan dan cukup nyata.Hasil glukosa darah cukup tinggi pada volume $850 \mu \mathrm{l}$ dan $1000 \mu \mathrm{l}$ dibandingkan pada volume 1200 $\mu$ l.Artinya, jika ada pengurangan reagen maka glukosa darah akan meningkat.

Dalam memipet sampel,perlu diperhatikan keadaan mikropipet dan tip.Tip harus dalam keadaan rapat pada mikropipet dan volume mikropipet harus sesuai dengan volume sampel dan reagen yang butuhkan.

Ada beberapa hal yang harus diperhatikan pada tahapan tes laboratorium.Tes analitik adalah tes specimen, kualitas reagen, penggunaan alat, analisis sesuai dengan pedoman dan dilakukan pada suhu tertentu serta kalkulasi hasil dan pelaporan disesuaikan dengan pedoman. (Hardjono , 2007) 


\section{KESIMPULAN}

Berdasarkan hasil penelitian tentang pengaruh variasi volume penggunaan reagensia pada pemeriksaan glukosa darah metode GOD-PAP yang telah dilakukan maka dapat disimpulkan bahwa volume reagen berpengaruh terhadap hasil pemeriksaan Glukosa Darah metode GOD-PAP dengan $\mathrm{F}$ hitung $(6,74)>$ Ftabel $(3,40)$ pada $\alpha=0,05$

\section{SARAN}

Berdasarkan kesimpulan diatas,saran yangn penulis berikan adalah Bagi teknisi laboratorium, sebaiknya menggunakan volume reagen yang sesuai dengan prodsedur tetap.

DAFTAR PUSTAKA

Atun, 2010. Diabetes Mellitus . Bantul

: Kreasi Wacana offset

Biokimia FKHUI , 2001. Biokimia

Eksperimen Laboratorium .

Jakarta: Widya Medika.
Colby

D,2011.

Biokimia

Harper.Jakarta : Kedokteran EGC

Depkes, 1995

Laboratorium Kesehatan

Jakarta : Depkes

Fox C, Kilvert A, 2011. Bersahabat dengan diabetes tipe 2.Jkarta : Penebar Plus

Hardjono ,2007 . interretasi Hasil Tes Laboratorium

Diagnostik.Makassar :Hasanuddin University Press

Kurnia K, 1985. Pengantar Instrumentasi Analisis Kimia . Bandung : Alumni Martoharsono S, 2006. Biokimia 2.Yogyakarta : GajahMada University Press

Muchtadi D , 2011. Karbohidrat Pangan dan Kesehatan. Bandung Alfabeta

Robbins LS, kumar V 1995. Patologi I . Jakarta : Buku Kedokteran EGC 